\title{
RGPD3 wt Allele
}

National Cancer Institute

\section{Source}

National Cancer Institute. RGPD3 wt Allele. NCI Thesaurus. Code C143083.

Human RGPD3 wild-type allele is located in the vicinity of 2 q12.2 and is approximately 77 $\mathrm{kb}$ in length. This allele, which encodes RanBP2-like and GRIP domain-containing protein 3, may involved in GTP-binding nuclear protein Ran localization. Mutations in the gene may be associated with endometrioid adenocarcinoma. 